\title{
Beekeeping Production System, Challenges, and Opportunities in Selected Districts of South Wollo Zone, Amhara, Ethiopia
}

\author{
Addisu Bihonegn (D) $^{1}$ and Desalegn Begna ${ }^{2}$ \\ ${ }^{1}$ Andassa Livestock Research Center, P.O. Box 27, Bahir Dar, Ethiopia \\ ${ }^{2}$ Ambo University, Animal Breading and Genetics, Ambo, Ethiopia \\ Correspondence should be addressed to Addisu Bihonegn; addbesh@gmail.com
}

Received 9 April 2021; Accepted 23 September 2021; Published 1 November 2021

Academic Editor: Innocenzo Muzzalupo

Copyright (c) 2021 Addisu Bihonegn and Desalegn Begna. This is an open access article distributed under the Creative Commons Attribution License, which permits unrestricted use, distribution, and reproduction in any medium, provided the original work is properly cited.

\begin{abstract}
The study was conducted in Tehulederie, Kalu, and Dessie Zuria districts of South Wollo Zone, Amhara, Ethiopia, to assess the current beekeeping production system with available opportunities and challenges facing the beekeeping subsector. The districts were purposively selected based on potential and accessibility and then stratified into lowland, midland, and highland. In total, 135 beekeepers, of which 126 were males and 9 were females, were interviewed using a pretested semistructured questionnaire. The result revealed that beekeeping is actively practiced by the community regardless of age and sex. Three beekeeping production systems, that is, traditional, transitional, and movable frame hive, have been identified, accounting for $80 \%$, $4 \%$, and $16 \%$, respectively. More than $80 \%$ of total bee colonies are managed being placed in the backyard. Besides, the study indicated that about $79 \%$ of the beekeepers keep bees primarily for income generation and home consumption. According to this study, the average bee colony holding size is 5.13 per a beekeeper. Also, this study identified that the swarm catching method is the major source of bee colony accounting for more than $45 \%$ to start beekeeping and $76 \%$ to increase existing colony number. Bee colony decline, absconding and swarming, honeybee pests and predators, and lack of training and extension were identified as major beekeeping challenges in the study areas. This study identified the beekeeping production system, opportunities, and challenges of the study areas and has significantly contributed to our knowledge and identified lack of extension and training as intervention areas. Therefore, practical beekeeping training and extension should get primary emphasis to combat the existing challenges.
\end{abstract}

\section{Introduction}

Beekeeping is important because it directly contributes to the outputs produced such as honey, beeswax, queen, and bee colonies and other products such as pollen, royal jelly, bee venom, and propolis in cosmetics and medicine [1]. Beekeeping plays a role in providing nutrition, economic, and ecological security as bees are valuable pollinators of both agricultural crops and natural ecosystems [2]. The business almost requires less land and less initial capital, does not take much part of the farmers' time, undertaken by the young and old, men and women, and does not compete with other components of farming systems for resources. It can also be a fascinating hobby, a profitable sideline, or a full-time occupation [3].
Beekeeping is an ancient practice in Ethiopian farming communities [4-6]. The country has substantial potential for beekeeping [7], with an immense diversification of melliferous plants [8] and proper ecological and climatic conditions that favor the existence of numerous bee colonies [9] and honeybee subspecies [10]. Beekeeping can significantly contribute to beekeeper's livelihoods and the country's economy [11]. At different levels, a significant number of people are engaged in trading honey and beeswax and selling local honey wines "Tej". This creates job and self-employment opportunities for a large number of citizens [12]. In Ethiopia, about 1.9 million farm households are involved in beekeeping, and there are about 10 million colonies out of which about 5.92 million are hived [9] and it is estimated that the country has the potential to produce 500,000 tons of honey and 50,000 
tons of beeswax per annum [13]. Recent production is estimated at 50,790 tons of honey in 2015/6 CSA [9] and about 5,344 tons of beeswax in 2013 [14].

South Wollo is one of the major potential zones of the Amhara region, endowed with diversified honeybee flora, 186,977 beehives, which accounts for $14.08 \%$ of the regional share, of which 183,090 beehives (97.92\%) are traditionally made from bamboo, mud, cow dung, and ash mixture [9]. About $1,137,859 \mathrm{~kg}$ of honey was produced in 2014/5 with an average productivity of $7.10 \mathrm{~kg} /$ hive/annum [15]. However, little research has been conducted on beekeeping production systems and existing challenges and opportunities in the South Wollo zone. Therefore, this study was designed to deliver valuable information on the current beekeeping production system, major challenges of the sector, and the available opportunities in selected districts of South Wollo zone, Amhara region, Ethiopia.

\section{Materials and Methods}

2.1. Description of the Study Areas. The study was conducted in three districts (Tehulederie, Kalu, and Dessie Zuria) of the South Wollo zone, considering variations in agroecology (mid, low, and highlands). South Wollo zone is one of the 11 zones of the Amhara region, having an area of $17,067.45 \mathrm{~km}^{2}$, located $10.200-11.71 \mathrm{~N}$ and $38.410-40.02 \mathrm{E}$ North of Ethiopia, whose main capital is Dessie, $401 \mathrm{~km}$ from Addis Ababa. The area has a long-term mean $(1162 \mathrm{~mm})$ rainfall per annum with monthly minimum and maximum temperatures of $12.6^{\circ} \mathrm{C}$ and $26.4^{\circ} \mathrm{C}$, respectively.

2.2. Sampling Techniques. A purposive sampling procedure was applied for the study districts according to the beekeeping potential, accessibility, and proximity to honey and beeswax marketing and processing routes. From each district, three kebeles (the lower level of administration in Ethiopia) were selected purposively. From each kebele, 15 beekeepers were randomly selected using a systematic random sampling technique. In total, 135 beekeepers were interviewed using a semistructured questionnaire.

2.3. Method of Data Collection. The study used both primary and secondary sources of data on the beekeeping production system, opportunities, and major challenges of the selected potential areas. Primary data were collected on socioeconomic characteristics (household characteristics, educational status, landholding, and bee colony), beekeeping situation (beekeeping experience, source of bee colony, reasons of engagement in beekeeping, honeybee colony holding size, placement of bee colony, and types of hives), major challenges (colony decline, absconding and swarming, honeybee pests and predators, and training and extension service), and available opportunities. Secondary data were used to select potential localities based on the number of honeybee colonies and honey production considering the three agroecologies acquired from Zonal and district agricultural offices.
2.4. Data Management and Statistical Analysis. All collected data were entered into Microsoft Excel 2007, and descriptive statistics such as percentage, frequency, mean, and standard deviation were used to analyze the data using Statistical Package for Social Science (SPSS) software version 20. Any items that cannot be captured through a quantitative analysis were analyzed qualitatively based upon interviews and group discussion with beekeepers and extension workers.

\section{Results and Discussions}

3.1. Household Characteristics. Of 135 sample beekeepers interviewed, $93.3 \%$ were male-headed and $6.7 \%$ were femaleheaded (Table 1). The very limited number of female participation in beekeeping in the study areas might be due to beekeeping is considered as the work of men [16]. Also, as reported in [17-20], women might not be economically empowered through beekeeping. There is also a report indicating a cultural barrier to women to undertake honey harvesting [1]. Of the total beekeepers interviewed, $92.6 \%$ are married, while $3.7 \%, 3 \%$, and $0.7 \%$ are widowed, single, and divorced, respectively (Table 1). Similar results have reported that the majority of beekeepers are married [4, 21-23].

This study found the mean age of respondents to be $43.6 \pm 1.2$ years, with a range of 20 to 73 years. The majority (91.1\%) of respondents were found in economically active age groups of 20-60 years (Table 1), suggesting high potential labor availability for beekeeping (Table 1). Similarly, $[22,24,25]$ reported a mean age of $44,45.05 \pm 10.45$ and $45.02 \pm 13.3$ years, respectively, engaged in beekeeping practices in Ethiopia. Age and experience have great implications on identifying local honeybees and their products and behaviors [21]. The family size of the interviewed beekeepers ranges from 1 to 13 with a mean of 5.2, and the majority of the respondents $(80.7 \%)$ had a family size of $>4$ (Table 1). Similarly, [26] identified an average family size of beekeepers to be 5.4 ranging from 1 to 10 . Large family sizes have a better chance for labor shares in farm activities and hence for beekeeping activities too [26, 27].

3.2. Educational Status of Respondents. The educational level of the beekeepers can have a significant impact in identifying and determining the type of development and extension services that need to be designed for the area [28] and significantly affect the probability of adoption [29]. According to this study, about $29.6 \%$ of beekeepers have no educational background, while $31.1 \%$ of the respondents received informal education that can only help them to read and write. On the other hand, about 39.3\% have formal education with different levels ranging from primary school to secondary school level (Table 2). Therefore, according to this study, the high level of education significantly influenced the effectiveness of improved beekeeping adoption. To this fact, the sample beekeepers with grades 9 to 12 have significantly $(P<0.05)$ higher bee colony holding $(11.0)$ than the beekeepers with lower grade and illiterates (Table 2). 
TABLE 1: Characteristics of the sample beekeeper respondents by districts.

\begin{tabular}{|c|c|c|c|c|c|c|c|c|c|}
\hline \multirow{3}{*}{ Beekeepers characteristics } & \multirow{3}{*}{ Variable } & \multicolumn{8}{|c|}{ Districts (frequency and percentage) } \\
\hline & & \multicolumn{2}{|c|}{ Tehulederie } & \multicolumn{2}{|c|}{ Kalu } & \multicolumn{2}{|c|}{ Dessie Zuria } & \multicolumn{2}{|c|}{ Total } \\
\hline & & Freq. & $\%$ & Freq. & $\%$ & Freq. & $\%$ & Freq. & $\%$ \\
\hline \multirow{3}{*}{ Sex of beekeeper } & Male & 39 & 86.66 & 43 & 95.56 & 44 & 97.78 & 126 & $93.33^{\mathrm{NS}}$ \\
\hline & Female & 6 & 13.34 & 2 & 4.44 & 1 & 2.22 & 9 & $6.67^{\mathrm{NS}}$ \\
\hline & Total & 45 & 100 & 45 & 100 & 45 & 100 & 135 & 100 \\
\hline \multirow{5}{*}{ Marital status } & Single & 2 & 4.44 & 1 & 2.22 & 1 & 2.22 & 4 & $2.96^{\mathrm{NS}}$ \\
\hline & Married & 39 & 86.66 & 43 & 95.56 & 43 & 95.56 & 125 & $92.59^{\mathrm{NS}}$ \\
\hline & Widowed & 3 & 6.66 & 1 & 2.22 & 1 & 2.22 & 5 & $3.7^{\mathrm{NS}}$ \\
\hline & Divorced & 1 & 2.22 & 0 & 0 & 0 & 0 & 1 & $0.74^{\mathrm{NS}}$ \\
\hline & Total & 45 & 100 & 45 & 100 & 45 & 100 & 135 & 100 \\
\hline \multirow{5}{*}{ Age of beekeepers } & Mean \pm SD & $44.62 \pm 13$ & $44.02 \pm 9.8$ & $42.11 \pm 13$ & $43.59 \pm 12^{\mathrm{NS}}$ & & & & \\
\hline & Range (min-max) & $25-73$ & $20-70$ & $23-72$ & $20-73$ & & & & \\
\hline & $20-40$ & 22 & 33.85 & 18 & 27.69 & 25 & 38.46 & 65 & 48.15 \\
\hline & $41-60$ & 18 & 31.03 & 26 & 44.83 & 14 & 24.14 & 58 & 42.96 \\
\hline & 61 and above & 6 & 50 & 1 & 8.33 & 5 & 41.67 & 12 & 8.89 \\
\hline \multirow{3}{*}{ Family size } & Male & \multirow{3}{*}{\multicolumn{2}{|c|}{$\begin{array}{c}2.44 \pm 1.2^{\mathrm{b}} \\
2.58 \pm 1.31 \\
5.02 \pm 2.05^{\mathrm{ab}}\end{array}$}} & \multirow{3}{*}{\multicolumn{2}{|c|}{$\begin{array}{c}3.02 \pm 1.54^{\mathrm{a}} \\
2.76 \pm 1.61 \\
5.78 \pm 2.38^{\mathrm{a}}\end{array}$}} & \multirow{3}{*}{\multicolumn{2}{|c|}{$\begin{array}{c}2.18 \pm 0.96^{\mathrm{b}} \\
2.62 \pm 1.11 \\
4.8 \pm 1.56^{\mathrm{b}}\end{array}$}} & \multirow{3}{*}{\multicolumn{2}{|c|}{$\begin{array}{c}2.55 \pm 1.297 \\
2.65 \pm 1.35^{\mathrm{NS}} \\
5.20 \pm 2.055\end{array}$}} \\
\hline & Female & & & & & & & & \\
\hline & Total & & & & & & & & \\
\hline
\end{tabular}

NS: the mean difference is not significant at 0.05 level; SD: standard deviation; letters in a row with different superscripts denote significant differences at $p<0.05$.

TABLE 2: Educational status and mean bee colony holding of the interviewed beekeepers.

\begin{tabular}{lccc}
\hline Educational status & \multicolumn{2}{c}{ Respondents } & $\begin{array}{c}\text { Bee colony } \\
\text { holding } \\
\text { Mean }\end{array}$ \\
\hline Frequency & Percentage & $4.625^{\mathrm{b}}$ \\
Basic (read and & 40 & 29.6 & $5.095^{\mathrm{b}}$ \\
write) & 42 & 31.1 & $4.455^{\mathrm{b}}$ \\
Grades 1-4 & 22 & 16.3 & $5.423^{\mathrm{b}}$ \\
Grades 5-8 & 26 & 19.3 & $11.000^{\mathrm{a}}$ \\
Grades 9-12 & 5 & 3.7 & 5.13 \\
Total & 135 & 100 & \\
\hline
\end{tabular}

Letters in a column with different superscripts denote significant differences at $p<0.05$.

3.3. Beekeeping Experience of Respondents. The level of beekeepers experience is the number of years that an individual is continuously involved in beekeeping after he/she owns a colony. Differences in beekeeping experience might be responsible to influence the attitude and adoption of new beekeeping technologies [30]. According to this study, $31.85 \%$ of the beekeepers have more than 15 years of beekeeping exercises in beekeeping (Table 3 ). This result agrees with the findings of [22] who reported a considerable proportion $(41.1 \%)$ of the beekeepers in South Wollo and Wag Himra zones with more than 15 years of experience in beekeeping and [17] 16.5 years for Sekota district beekeepers. Those beekeepers with less than five years of experience accounted only for $23.70 \%$ of the total respondents (Table 3 ). This result was in line with the results of Kebede et al. [23] and Alemu [22]. According to the survey result, as beekeepers acquire the experience, they keep a higher colony number and gain enhanced honey production than the less experienced ones (Table 3).
TABLE 3: Beekeeping experience of respondents.

\begin{tabular}{lccc}
\hline $\begin{array}{l}\text { Beekeeping } \\
\text { experience }\end{array}$ & Frequency & Percent & $\begin{array}{c}\text { Mean colony } \\
\text { holding }\end{array}$ \\
\hline 1-5 years & 32 & 23.70 & 3.79 \\
5-10 years & 34 & 25.19 & 6.03 \\
10-15 years & 26 & 19.26 & 4.50 \\
More than 15 years & 43 & 31.85 & 4.96 \\
\hline
\end{tabular}

3.4. Source of Bee Colony. The majority (45.2\%) of the respondents in the study areas get their starter bee colony from swarm catching (Figure 1), and this agrees with the findings of Alemu [22] and Kebede and Tadesse [19], who reported that $50.3 \%$ and $60.3 \%$ of the respondents at South Wollo and Wag Himra zone and Hadya zone, respectively. Swarm catching includes the natural swarm from own colonies, bypass bee colony swam baits, and feral bee colonies in the forests. According to this study, the beekeepers prefer and practice swarm catching as major means of obtaining bee colonies since it is cost-free, convenient to keep in traditional beehives, and lacks know-how about artificial means of queen rearing techniques. On the other hand, $17 \%$ of the respondents buy colonies and $17 \%$ of the respondents get colonies from parents as a gift or inheritance (Figure 1). Newly engaged beekeepers that get their starter colony from their parents have more experience than those started from training or by their motivation, and this might be due to the accumulated experience while assisting their parents [23].

According to this study, more than $94 \%$ of the respondents agree that bee colony selling is practiced in the study areas with an average current price of $936.22 \mathrm{ETB}$. The price of an established traditional colony differs from kebele to kebele or farmer to farmer according to bee colony strength and bargaining power ranging from 300 to 1500 


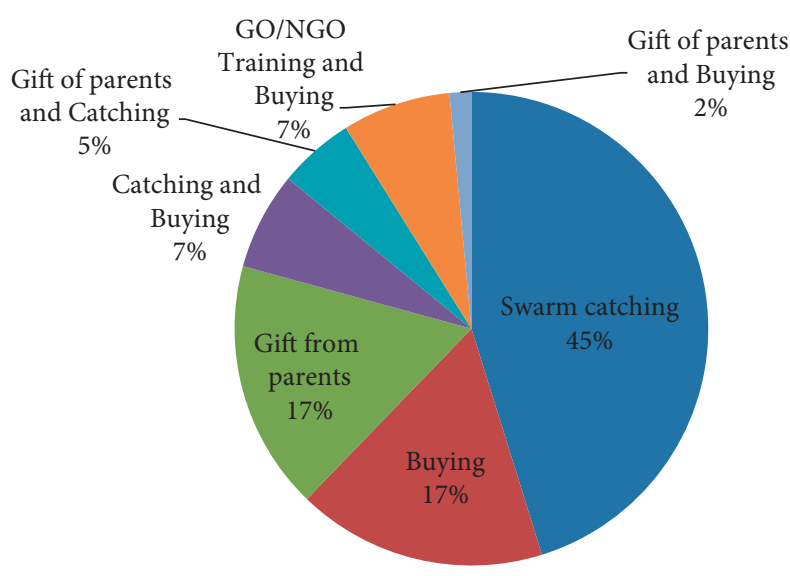

FIgURE 1: Source of starter bee colony in the study areas.

ETB. The study indicated that there is an increasing trend of bee colony price from time to time due to the increasing demand of bee colony and the decreasing trend of a bee colony in the study areas (Table 4). To increase their bee colony, the majority $(75.6 \%)$ of the respondent beekeepers acquire through catching swarm bees and the rest through buying, splitting, overcrowding, and/or the combination of them (Figure 2).

3.5. Reasons of Engagement in Beekeeping. According to the study result, $52.99 \%$ and $30.60 \%$ of the respondents keep bees primarily for income generation and home consumption, respectively, whereas $69.77 \%$ of the respondents rank home consumption as a secondary preference (Table 5). This result is in line with [22], which investigated $94.8 \%$ of the beekeepers produce attractive comb honey for both sale and home consumption at South Wollo and Wag Himra zone. However, [24] reported $59.4 \%$ of the beekeepers in the Tigray region keep their bee colonies for selling honeybee colony as honeybee colony marketing in the region is common at central market places and individual apiaries (Table 5).

3.6. Honeybee Colony Holdings. The average honeybee colony holding of the sample respondents is 5.1 (Table 6), demonstrating that the area is suitable for beekeeping development. More specifically, beekeepers own on average more traditional hives (4.1) than moveable frame hives (0.8) and top bar hive (0.2) (Table 6). Accordingly, out of 693 bee colonies in the study area, $79.94 \%, 4.04 \%$, and $16.02 \%$ of the honeybee colonies were hived in traditional, transitional, and frame hives, respectively (Table 6). The product volume and quality of the product are low for traditional hives $[4,31]$. However, beekeepers preferred traditional hives for their low input price and operation cost [31], availability [23], convenience to construct, more quantity of wax produced and less dependency on external inputs, and convenience to be used as a bait hive [4].

The majority (76.30\%) of the farmers who participated in the study have a colony number below six (Figure 3), suggesting smallholder beekeeping system is prevailing in
TABle 4: Reasons of colony decline.

\begin{tabular}{lccc}
\hline Reason for colony decline & Frequency & $\%$ & $\begin{array}{c}\text { Order of } \\
\text { importance }\end{array}$ \\
\hline Chemical application & 85 & 62.96 & 1 \\
Lack of management & 63 & 47.41 & 2 \\
Predators & 62 & 45.93 & 3 \\
Pests & 39 & 28.89 & 4 \\
Drought & 31 & 22.96 & 5 \\
Absconding & 22 & 16.30 & 6 \\
Swarming & 19 & 14.07 & 7 \\
Unknown reason & 17 & 13.33 & 8 \\
Lack of bee forages & 14 & 10.37 & 9 \\
Lack of water & 9 & 6.67 & 10 \\
Others (theft, climate & 4 & 2.96 & 11 \\
change) & 0 & 0.00 & \\
Diseases & &
\end{tabular}

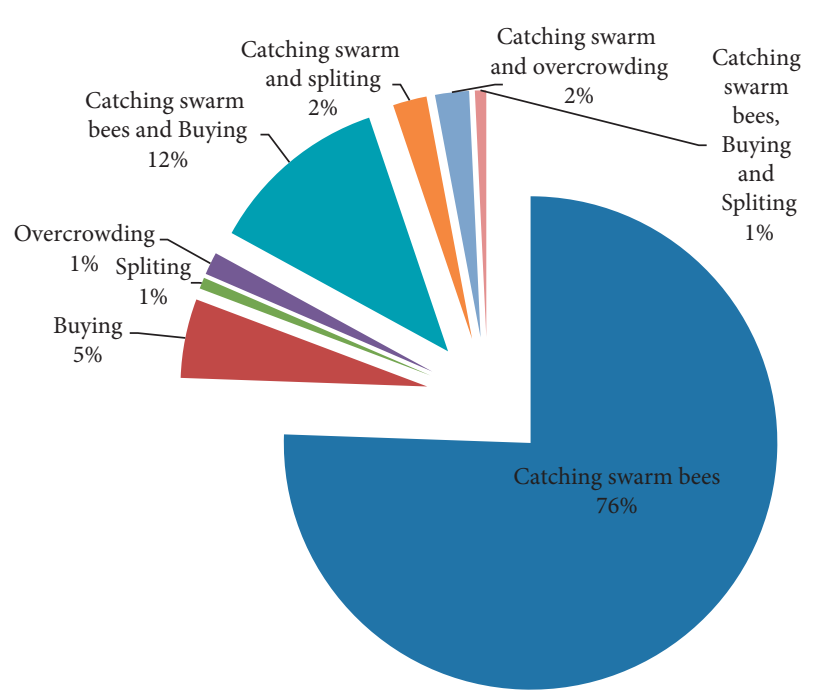

FIGURE 2: Methods of increasing bee colony in the study areas.

the study areas. The result was very comparable with the results from Kilte Awlaelo, Sekota, and Burie districts that are reported as 5.79, 5.9, and 6.48 colonies per beekeeper, respectively $[4,17,32]$.

3.7. Beehive Placement. In the study areas, $80.38 \%$ of the total colony and $73.88 \%$ of traditional colonies are placed at backyards indicating that backyard beekeeping is a common practice of honey production in the study areas, and this agrees with the findings of $[19,22,33]$ that establish more proportion of beekeeping at backyards. Backyards are easier for frequent inspection and other hive managements (including swarm prevention, pest and predator control, and quality honey production) compared with free apiaries [20]. The share of traditional colonies kept at the backyard is higher in Tehulederie $86.03 \%$ than Kalu (69.76\%) and Dessie Zuria $(69.55 \%)$. There is no single beekeeper that puts his beehives inside the house and hangs on trees in forests (Table 7). Reference [22] also confirmed that all the traditional beehives from the South Wollo zone and Wag-Khimra Zone are kept at the backyard and under the eaves of the house. 
TABLE 5: Rank index for reasons of engaging in beekeeping.

\begin{tabular}{|c|c|c|c|c|c|c|}
\hline \multirow{2}{*}{ Reason } & \multicolumn{4}{|c|}{ Priority frequency (\%) } & \multirow{2}{*}{ Index value } & \multirow{2}{*}{ Overall rank } \\
\hline & $1^{\text {st }}$ & $2^{\text {nd }}$ & $3^{\text {rd }}$ & Total & & \\
\hline Income & $71(52.99)$ & $2(4.65)$ & - & $73(39.89)$ & 0.44 & 1 \\
\hline Home consumption & $41(30.60)$ & $30(69.77)$ & - & $71(38.80)$ & 0.37 & 2 \\
\hline Hobby & $14(10.45)$ & $8(18.60)$ & $6(100)$ & $28(15.30)$ & 0.13 & 3 \\
\hline Others (training) & $8(5.97)$ & $3(6.98)$ & - & $11(6.01)$ & 0.06 & 4 \\
\hline Total & 134 & 43 & 6 & 283 & 1 & \\
\hline
\end{tabular}

Index $=\operatorname{sum}$ of $\left(3^{*}\right.$ ranked $1^{\text {st }}+2^{*}$ ranked $2^{\text {nd }}+1^{*}$ ranked $\left.3^{\text {rd }}\right)$ for individual reason divided by the sum of $\left(3^{*}\right.$ ranked $1^{\text {st }}+2^{*}$ ranked $2^{\text {nd }}+1^{*}$ ranked $\left.3^{\text {rd }}\right)$ for over all reasons.

TABLE 6: Honeybee colony holdings and share of colony holding.

\begin{tabular}{|c|c|c|c|c|c|c|c|c|c|}
\hline \multirow{2}{*}{ Parameters } & \multirow{2}{*}{ Hive type } & \multicolumn{2}{|c|}{ Tehulederie } & \multicolumn{2}{|c|}{ Kalu } & \multicolumn{2}{|c|}{ Dessie Zuria } & \multicolumn{2}{|c|}{ Overall } \\
\hline & & Total & Mean \pm SD & Total & Mean \pm SD & Total & Mean \pm SD & Total & Mean \pm SD \\
\hline \multirow{4}{*}{ Number of beehives } & Traditional & 159 & $3.53 \pm 1.92$ & 203 & $4.51 \pm 5.51$ & 192 & $4.27 \pm 6.79$ & 554 & $4.10 \pm 2.60^{\mathrm{NS}}$ \\
\hline & Transitional & 2 & $0.04 \pm 1.95$ & 5 & $0.11 \pm 2.83$ & 21 & $0.47 \pm 2.86$ & 28 & $0.21 \pm 1.82^{\mathrm{NS}}$ \\
\hline & Frame & 18 & $0.40 \pm 0.21$ & 40 & $0.89 \pm 0.38$ & 53 & $1.18 \pm 3.13$ & 111 & $0.81 \pm 4.13^{\mathrm{NS}}$ \\
\hline & Total & 179 & $3.98 \pm 1.92$ & 248 & $5.51 \pm 5.51$ & 266 & $5.91 \pm 6.79$ & 693 & $5.13 \pm 5.20^{\mathrm{NS}}$ \\
\hline \multirow{6}{*}{ Share of colony holding } & \multirow{2}{*}{ Hive type } & \multicolumn{2}{|c|}{ Tehulederie } & \multicolumn{2}{|c|}{ Kalu } & \multicolumn{2}{|c|}{ Dessie Zuria } & \multicolumn{2}{|c|}{ Over all } \\
\hline & & Total & $\%$ & Total & $\%$ & Total & $\%$ & Total & $\%$ \\
\hline & Traditional & 159 & 88.83 & 203 & 81.85 & 192 & 72.18 & 554 & 79.94 \\
\hline & Transitional & 2 & 1.12 & 5 & 2.02 & 21 & 7.89 & 28 & 4.04 \\
\hline & Frame & 18 & 10.06 & 40 & 16.13 & 53 & 19.92 & 111 & 16.02 \\
\hline & Total hives & 179 & 100 & 248 & 100 & 266 & 100 & 693 & 100 \\
\hline
\end{tabular}

SD: standard deviation; NS: the mean difference is not significant at 0.05 level; traditional: hives made of locally available materials like bamboo and tree branches and coated by mud and ash; transitional: Kenyan TBH; frame: Langstroth frame hives.

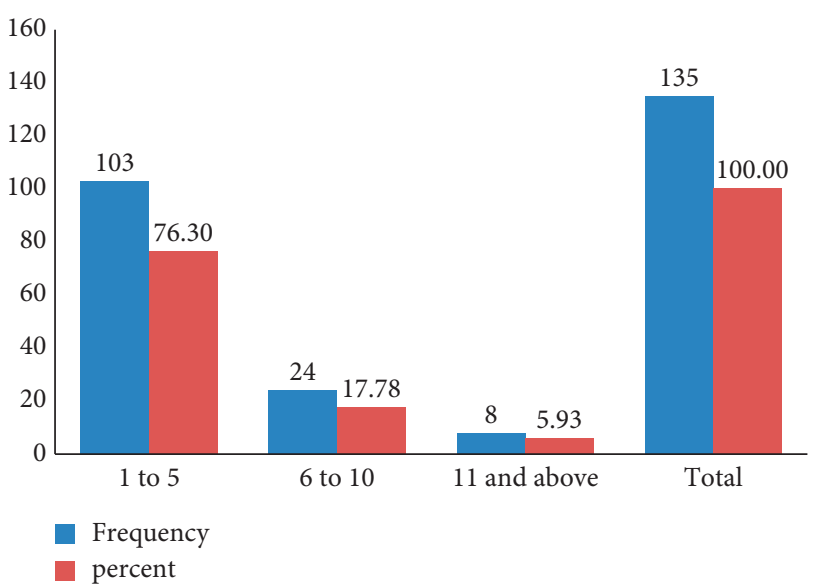

FIGURE 3: Frequency and percentage of bee colony ownership in the study areas.

3.8. Honeybee Colony Decline. Despite the potential of the study areas for beekeeping, in recent years, there has been a decreasing trend of honeybee colony populations. According to this study, $96.3 \%$ of the respondents agreed on the decreasing trend of bee colonies due to different threatening factors on bees and their products. Based on this fact, $60.74 \%, 46.67 \%, 45.93 \%, 27.41 \%$, and $22.22 \%$ of the respondents put pesticide and herbicide application on crops, lack of management, predators, pests, and drought, respectively, as major reasons for the colony decline in the study areas. No honeybee disease was reported as a threatening factor for colony decline in the study areas
(Table 4), and this might not reflect the absence of bee disease in the study area but might reflect lack of close observation and/or lack of skill in identifying pathogens among beekeepers. Owing to multiple factors, Alemu [22]; Kebede et al. [23]; Belie [4]; and Alemu [5] have reported bee colony decline trend in Wag Himra and South Wollo zones, Amhara Region, Bure, and Sekota, respectively.

Unwise application of agrochemicals was the major issue reported by beekeepers and accounted for $62.96 \%$ of the factors (Table 4) that caused the significant effect on bee colony decline in the study areas [22], and its damage has been acknowledged at regional and country levels [34]. According to this study, the intensity of chemical application is higher in Kalu district in the irrigable areas in July to November to control and/or treat animal and crop pests and diseases. The chemical application time in the study areas is set by Knapsack sprayer owners or renters as also reported by [34]. A threat from wider agrochemical brands application is a challenge from nonbeekeepers [34]. It has been also reported that more than $82.4 \%$ of the respondent beekeepers in the South Wollo and Wag Himra zone [22] and 54\% in Mecha, Dangla, and Guangua districts [34] are using agrochemicals in their localities.

3.9. Absconding. Honeybee colonies abandon their hive at any season of the year for different reasons [35]. Absconding is a common phenomenon, especially in the case of ill management as a response to disturbance [36]. This study revealed that absconding is very serious and $98.52 \%$ of the respondents in the study areas agreed on the prevalence of 
Table 7: Placement of beehives in the study areas.

\begin{tabular}{|c|c|c|c|c|c|c|c|c|c|}
\hline \multirow{3}{*}{ Placement of hives } & \multirow{3}{*}{ Hive type } & \multicolumn{8}{|c|}{ Districts } \\
\hline & & \multicolumn{2}{|c|}{ Tehulederie } & \multicolumn{2}{|c|}{ Kalu } & \multicolumn{2}{|c|}{ Dessie Zuria } & \multicolumn{2}{|c|}{ Total } \\
\hline & & Freq. & $\%$ & Freq. & $\%$ & Freq. & $\%$ & Freq. & $\%$ \\
\hline \multirow{3}{*}{ Backyard } & Traditional & 154 & 86.03 & 173 & 69.76 & 185 & 69.55 & 512 & 73.88 \\
\hline & Transitional & 2 & 1.12 & 2 & 0.81 & 0 & 0.00 & 4 & 0.58 \\
\hline & Frame & 18 & 10.06 & 16 & 6.45 & 7 & 2.63 & 41 & 5.92 \\
\hline \multirow{3}{*}{ Apiary site } & Traditional & 0 & 0.00 & 22 & 8.87 & 4 & 1.50 & 26 & 3.75 \\
\hline & Transitional & 0 & 0.00 & 3 & 1.21 & 21 & 7.89 & 24 & 3.46 \\
\hline & Frame & 0 & 0.00 & 23 & 9.27 & 45 & 16.92 & 68 & 9.81 \\
\hline \multirow{3}{*}{ Under the eaves of the house } & Traditional & 5 & 2.79 & 7 & 2.82 & 3 & 1.13 & 15 & 2.16 \\
\hline & Transitional & 0 & 0.00 & 0 & 0.00 & 0 & 0.00 & 0 & 0.00 \\
\hline & Frame & 0 & 0.00 & 0 & 0.00 & 1 & 0.38 & 1 & 0.14 \\
\hline \multirow{3}{*}{ Inside the house } & Traditional & 0 & 0.00 & 0 & 0.00 & 0 & 0.00 & 0 & 0.00 \\
\hline & Transitional & 0 & 0.00 & 0 & 0.00 & 0 & 0.00 & 0 & 0.00 \\
\hline & Frame & 0 & 0.00 & 0 & 0.00 & 0 & 0.00 & 0 & 0.00 \\
\hline \multirow{3}{*}{ Hanging on trees near homestead } & Traditional & 0 & 0.00 & 1 & 0.40 & 0 & 0.00 & 1 & 0.14 \\
\hline & Transitional & 0 & 0.00 & 0 & 0.00 & 0 & 0.00 & 0 & 0.00 \\
\hline & Frame & 0 & 0.00 & 1 & 0.40 & 0 & 0.00 & 1 & 0.14 \\
\hline \multirow{3}{*}{ Hanging on trees in forests } & Traditional & 0 & 0.00 & 0 & 0.00 & 0 & 0.00 & 0 & 0.00 \\
\hline & Transitional & 0 & 0.00 & 0 & 0.00 & 0 & 0.00 & 0 & 0.00 \\
\hline & Frame & 0 & 0.00 & 0 & 0.00 & 0 & 0.00 & 0 & 0.00 \\
\hline Total & 179 & & 248 & & 266 & & 693 & & \\
\hline
\end{tabular}

bee colony absconding in their site/locality. Attacks from pest, drought, and management problems are taking the share of $29 \%, 17.9 \%$, and $15 \%$, respectively. It is also reported that $20 \%$ of the respondent beekeepers do not know the reason for absconding (Table 8). Pest attack, mainly wax moth, is prominently a serious problem triggering bee colony to abscond. This study showed that bee colony absconding prevails during the dearth period especially from April to June, and this agrees with the result of [22] as prolonged dearth periods cause bee forage scarcity. The mean number of bee colony absconded in the sample respondents was 2.23 per beekeeper within the last three years (Table 8). This figure agrees with the result of [4], which reported 2.6 mean bee colonies absconded per beekeeper at the Burie district.

From the total of absconded colonies, $81.2 \%$ were from traditional hives due to the reasons of inconveniency for management and being easily attacked by pests (Table 8 ). The absconded bees from frame hives were only $9 \%$, and this might be due to skill development made on frame hives concerning its seasonal management and pest control to minimize absconding. Beekeepers within the study area tried to regulate absconding through frequent inspection $(21.80 \%)$, feeding and watering (17.59\%), pest control (11.09\%), cleaning sites $(10.90 \%)$, and other options. Also, $19.5 \%$ of respondent beekeepers are not applying any options to control the absconding of bee colonies (Table 8).

3.10. Reproductive Swarming. Reproductive swarming is the natural way in which honeybee colonies reproduce. That means some workers move from the colony with virgin or mated queens to a new place and cooperate to build their new nest. Swarming behavior gives an extension to the life of honeybee colonies where the mother colony can live for a long time and multiple swarms can result from it [37]. In this study, $93.3 \%$ of the respondents appreciated the existence of swarming (Table 9). Although there exists a small portion of swarming in frame hives (5.56\%), the most frequent swarming was observed in traditional hives (91.27\%). This might be due to the small size of traditional beehives that induce overcrowding so that the bee colonies are forced to issue swarm. The effect of temperature and the quality of the traditional beehives from which it is constructed are listed to have an impact (Table 9). In contrast to absconding, swarming is more prominent from September to October, and this is in line with [38] that established swarming is frequent in September and in April in the Supé and Bonga of southern Ethiopia, respectively.

According to the discussion, beekeepers kill the successive swarms after catching the first one to three strong swarms. This may be because the construction of a new nest with wax requires a sufficient amount of food and a larger number of bees [37]. According to this study, if conditions are favorable, the frequency of swarming is every year $(70 \%)$ and once in two years (15.4\%) (Table 9).

3.11. Swarm Control. Swarm control is important to minimize the risk of honeybee colony working force loss. Beekeepers in the study areas use different means of bee colony swarm control so that the issued swarm bee colonies remain under their control. Queen cell removal before the queen hatch out $(25.8 \%)$, reuniting swarm back to mother colony by killing the queen (20.3\%), and honey comb harvest $(19.4 \%)$ (Table 10) are among techniques practiced by the beekeeper to control the swarm. This result agrees with Belie's [4] result that established that about, $85.80 \%$ of the 
TABLE 8: Absconding of honeybee colonies in the study areas.

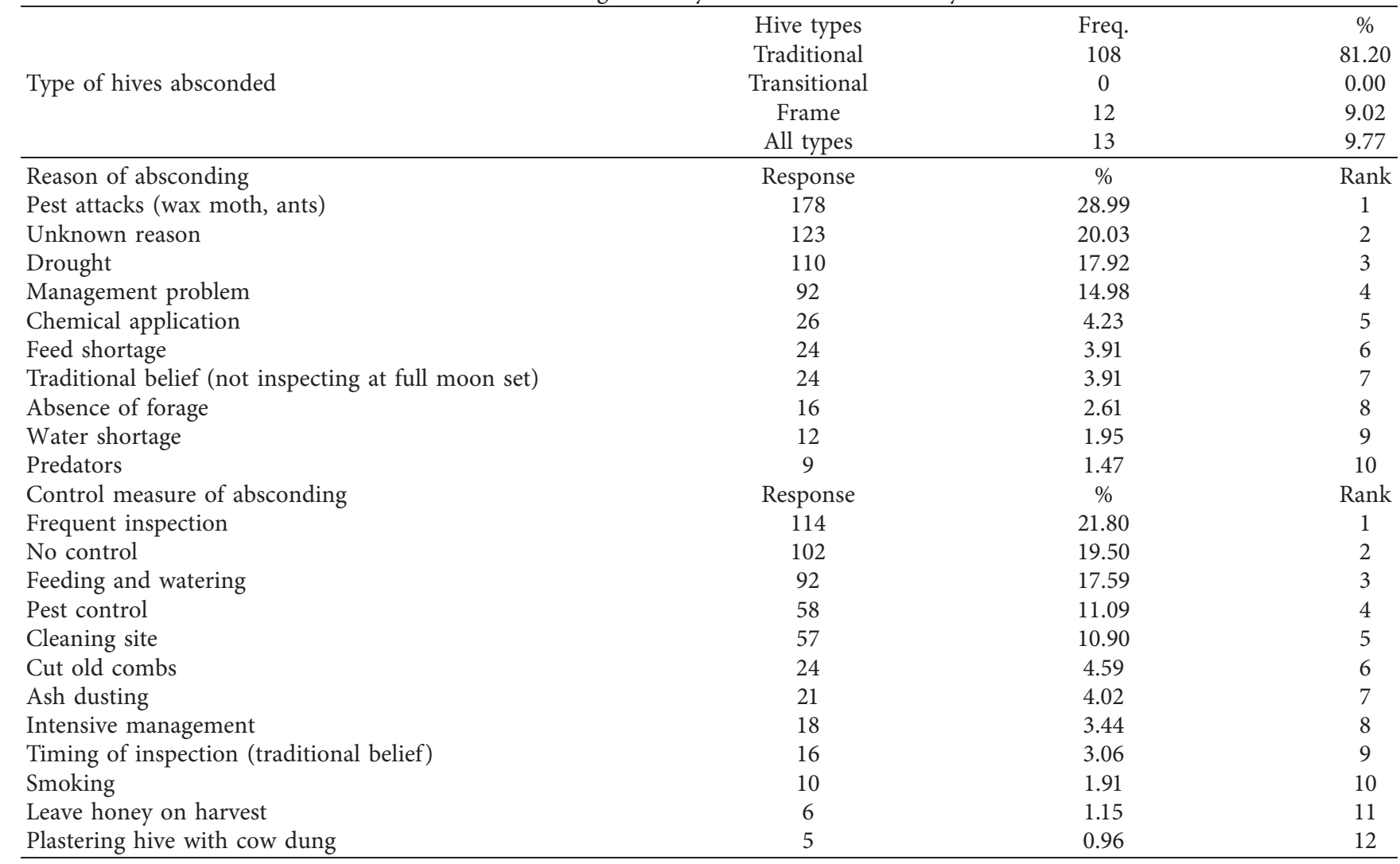

TABLE 9: Beekeepers response to reproductive swarming of honeybees in the study areas.

\begin{tabular}{|c|c|c|c|c|}
\hline Parameter & Response & Frequency & Percent & Cumulative (\%) \\
\hline \multirow{2}{*}{ Is there swarming? } & No & 9 & 6.7 & 6.7 \\
\hline & Yes & 126 & 93.3 & 100.0 \\
\hline \multirow{3}{*}{ From which type of hive? } & Traditional & 115 & 91.27 & 91.27 \\
\hline & Frame & 7 & 5.56 & 96.83 \\
\hline & All & 4 & 3.17 & 100.00 \\
\hline \multirow{8}{*}{ Frequency of swarming } & Every year & 91 & 70.00 & 70.00 \\
\hline & Once in two years & 20 & 15.38 & 85.38 \\
\hline & Not known & 9 & 6.92 & 92.31 \\
\hline & Every three years & 4 & 3.08 & 95.38 \\
\hline & Two to three years & 2 & 1.54 & 96.92 \\
\hline & Two to four years & 2 & 1.54 & 98.46 \\
\hline & Four or five years & 1 & 0.77 & 99.23 \\
\hline & Three to five years & 1 & 0.77 & 100.00 \\
\hline
\end{tabular}

sample respondents have experience of catching incidental swarms that can be transferred to other hives (70.3\%), return to the original hive (34.2\%), and offer for selling (4.4\%).

3.12. Honeybee Pests and Predators. The beekeeping production system of the study areas reported to face a multitude of challenges and pests and predators are recognized as major ones. Pests endanger honeybee life and their product and lead the colonies to abscond or die (Table 9). Many research findings also confirmed pests and predators as major threatening factors for honeybees and beekeeping business $[6,22,25,39]$. The results from this survey study have identified birds, ants, wax moths (Galleria mellonella), lizards, honey badgers (Mellivora capensis), spiders, wasps, beetles, bee lice (Braula coeca), and termites as the major honeybee pests and predators in order of their decreasing importance (Table 11).

Also, the cross-sectional studies conducted at South Wollo zone and Wag Himra zone have identified ants, wax moths, bee-eating birds, varroa mites, wasps, lizards, spiders, bee lice, death head hawks moth, and honey badger as major pests and predators in order of importance [22]. A similar study conducted in the selected district of the Tigray region recognized ants, birds, spiders, mites, wax moths, beetle, bee mice, honey badger, cat worm, and lizards as major 
TABLe 10: Method of swarm control.

\begin{tabular}{|c|c|c|c|c|}
\hline Parameter & Response & Frequency & Percent & Rank \\
\hline \multirow{14}{*}{ Method of swarm control } & Removal of queen cells & 84 & 25.85 & 1 \\
\hline & Harvest honey comb & 63 & 19.38 & 3 \\
\hline & Return back to mother colony & 66 & 20.31 & 2 \\
\hline & Supering & 20 & 6.15 & 6 \\
\hline & Use large volume hive & 27 & 8.31 & 5 \\
\hline & Smoking the hive with Boswellia papyrifera & 40 & 12.31 & 4 \\
\hline & Cut brood combs & 4 & 1.23 & 9 \\
\hline & Cut old combs & 4 & 1.23 & 9 \\
\hline & Regular inspection & 6 & 1.85 & 7 \\
\hline & Attach queen excluder at entrance & 2 & 0.62 & 11 \\
\hline & Smoking with camel dung & 2 & 0.62 & 11 \\
\hline & Smoking with mule bone & 5 & 1.54 & 8 \\
\hline & Smoking with bamboo root & 1 & 0.31 & 13 \\
\hline & Smoking with Hayginia abissinica flower & 1 & 0.31 & 13 \\
\hline
\end{tabular}

TABLE 11: Honeybee pests and predators of in the study areas.

\begin{tabular}{lccccccccc}
\hline \multirow{2}{*}{ Honeybee pest and predators } & \multicolumn{4}{c}{ Relative degree of importance } & \multicolumn{3}{c}{ Score } & \multicolumn{2}{c}{ Index } \\
& $1^{\text {st }}$ & $2^{\text {nd }}$ & $3^{\text {rd }}$ & $4^{\text {th }}$ & $5^{\text {th }}$ & $6^{\text {th }}$ & $7^{\text {th }}$ & Rank \\
\hline Birds & 40 & 54 & 22 & 7 & - & - & - & 742 & 0.260 \\
Ants & 53 & 19 & 31 & 11 & 2 & - & - & 690 & 0.242 \\
Wax moth & 13 & 20 & 24 & 14 & 4 & 5 & - & 409 & 0.144 \\
Lizard & 13 & 21 & 15 & 17 & 5 & 2 & 1 & 380 & 0.133 \\
Honey badger & 7 & 6 & 12 & 20 & 4 & 3 & - & 243 & 0.085 \\
Spiders & - & 6 & 13 & 5 & 8 & 2 & 3 & 152 & 0.053 \\
Wasps & 3 & 5 & 7 & - & 5 & 1 & 2 & 105 & 0.037 \\
Beetles & - & 1 & 4 & 9 & 6 & 1 & - & 82 & 0.029 \\
Bee lice & - & 2 & 3 & - & 3 & - & 1 & 37 & 0.013 \\
Termite & - & 1 & - & 1 & - & - & - & 10 & 9 \\
\hline
\end{tabular}

Index $=\operatorname{sum}$ of $\left(7^{*}\right.$ ranked $1^{\text {st }}+6^{*}$ ranked $2^{\text {nd }}+5^{*}$ ranked $3^{\text {rd }}+4^{*}$ ranked $4^{\text {th }}+3^{*}$ ranked $5^{\text {th }}+2^{*}$ ranked $6^{\text {th }}+1^{*}$ ranked $\left.7^{\text {th }}\right)$ for individual reasons divided by the sum of $\left(7^{*}\right.$ ranked $1^{\text {st }}+6^{*}$ ranked $2^{\text {nd }}+5^{*}$ ranked $3^{\text {rd }}+4^{*}$ ranked $4^{\text {th }}+3^{*}$ ranked $5^{\text {th }}+2^{*}$ ranked $6^{\text {th }}+1^{*}$ ranked $\left.7^{\text {th }}\right)$ for over all reasons.

TABLE 12: Beekeeping extension and training in the study areas.

\begin{tabular}{lccc}
\hline Parameters & Variable & Frequency & \\
\hline \multirow{2}{*}{ Did you get beekeeping extension service? } & Yes & 24 & 17.78 \\
& No & 111 & 82.22 \\
\hline \multirow{2}{*}{ Do you take beekeeping training? } & Yes & 52 & 38.52 \\
\hline
\end{tabular}

honeybee pests and predators [24, 40]. Likewise, in the Amhara region [23], ants, wax moths, bee-eater birds, spiders, bee lice, honey badger, termite, small hive beetles, and snake were the most harmful pests in order of importance. Moreover, [39] also identified ants, honey badgers, beetles, birds, wax moths, spiders, mites, lizards, bee lice, and toads as the most threatening pests and predators in Sidama and Gedeo zones of Southern Ethiopia.

3.13. Extension and Training. Extension and training packages are crucial for the government sectors for improved technology interventions as well as policy and regulations disseminations. Beekeeping training develops the beekeepers' self-confidence in using technology and increases the productivity of the beekeepers. According to this study, only $17.8 \%$ of the beekeepers received beekeeping extension service on improved beekeeping technologies from the district development agents. However, the majority of the respondents (82.2\%) did not get any beekeeping extension service (Table 12). This result is in line with the result of [23] who reported that only $33.2 \%$ of the sample respondents had the chance of getting extension service delivery in the Amhara region. Lower beekeeping extension services influence the adoption of improved beekeeping technologies [41]. The extension services delivered to the study area beekeepers were just provision of inputs like smokers, frame beehives, beeswax, honey extractor, casting mold, beekeepers suit, starter colony, and money along with training on basic seasonal bee management and honey harvesting. Besides, newly engaged farmers are encouraged to buy frame beehives after training. 


\section{Conclusions and Recommendations}

Beekeepers in South Wollo keep bees primarily to generate income and also partly use bee products for home consumption. Beekeeping in the area is largely practiced by men and the involvement of women is culturally impaired. Beekeepers within the ranges of active age groups (20-60 years) are largely involved in beekeeping practices. Although most of the beekeepers have 15 and more years of beekeeping experience, still traditional beekeeping is prevailing and the bee colony holding of an individual is small. Due to a lack of improved skills and knowledge on artificial queen rearing, still, bee colony swarm catch by hanging bait hives on long trees is a major means of colony obtaining. Unwise use of agrochemicals, seasonal shortage of bee forage, bee pests and undesirable characteristics of the bees (absconding, swarming), and lack of adequate and appropriate extension services are identified as major challenges of beekeeping development in the areas. Great emphasis should be given to training and extension programs for the beekeepers focusing on the practical aspects of general beekeeping and more specifically on honeybee management, pest and predator prevention, and/or control methods.

This study identified beekeeping production, challenges, and opportunities in the South Wollo zone. Furthermore, the study generated more quantitative data that can fill the information gap on the general aspects of beekeeping in the study areas and boldly showed intervention areas to the policymakers and development practitioners.

\section{Data Availability}

The data that support the findings of this study are available from the corresponding author, Bihonegn, upon reasonable request.

\section{Disclosure}

This manuscript is part of the thesis work entitled "Assessment of Beeswax Production, Quality and Market Chains in Selected Districts of South Wollo Zone, Amhara Region, Ethiopia."

\section{Conflicts of Interest}

The authors declare that they have no conflicts of interest.

\section{Acknowledgments}

The authors would like to thank all study areas' District Office of Agriculture and their respective experts for facilitating and providing all necessary information. Besides, the authors would like to thank the Livestock and Irrigation Value Chains for Ethiopian Smallholders (LIVES) project for its financial support. Finally, the authors would like to express gratitude to Sekota Dryland Agricultural Research Center and its staff for their assistance to conduct this study. The authors also would like to thank CGIAR, https:// cgspace.cgiar.org/, for uploading the thesis.

\section{References}

[1] W. Abebe, "Determinants of adoption of improved box hive in Atsbi Wemberta district of Eastern Zone, Tigray Region," MSc. thesis, Haramaya University, Ethiopia, 2007.

[2] A. Dafar, "Review of economical and ecological importance of bee and bee products in Ethiopia," Journal of Animal Husbandry and Dairy Science, vol. 2, no. 2, pp. 18-26, 2018.

[3] B. Meaza Gebreyohannes, "Socio-economic analysis of market oriented beekeeping in Atsbi Wemberta district of Eastern Zone, Tigray Region," M. A thesis, Mekelle University, Department of Management, Mek'ele, Ethiopia, 2010.

[4] T. Belie, "Honeybee production and marketing systems: constraints and opportunities in Burie district of Amhara Region, Ethiopia," M. Sc thesis, Dissertation for Award of MSc Degree at Bahir Dar University, Bahirdar University, Department of Animal Science and Technology, Ethiopia, 2009.

[5] T. Alemu, "Assessment of honeybee production practices and honey quality in Sekota Woreda of Waghimra zone," M.Sc. thesis, Haramaya University, Department of Animal Sciences, Ethiopia, 2010.

[6] A. Tesfa, K. Ejigu, and A. Kebede, "Assessment of current beekeeping management practice and honeybee floras of western Amhara, Ethiopia," International Journal of Agriculture and Biosciences, vol. 2, no. 5, pp. 196-201, 2013, http:// www.ijagbio.com/pdf-files/volume-2-no-5-2013/196-201.pdf.

[7] J. Agonafir, "SNV support to business organisations and their access to markets (Boam) strategic intervention plan on honey \& beeswax value chains," 2005.

[8] G. Godifey and A. Tassew, "Importance of integrating beekeeping with closure areas in Ethiopia: status and future prospects," Journal of Biology, Agriculture and Healthcare, vol. 6, no. 3, pp. 30-41, 2016.

[9] Central Statistical Agency, Agricultural sample survey 2015/ 16 [2008 E. C] volume II: report on Livestock and Livestock characteristics (private peasant holdings). 2016 In STATISTICAL BULLETIN 583: Vol. II (Issue June 2016). Federal Democratic Republic of Ethiopia Central Statistical Agency (CSA). http://www.csa.gov.et/images/general/news/live_ stock_2015_16, 2016.

[10] A. Bezabeh, N. Adgaba, S. E. Radloff, and H. R. Hepburn, "Multivariate morphometric analysis of honeybees (Apis mellifera) in the Ethiopian region," Apidologie, vol. 35, no. 1, pp. 71-81, 2004, https://doi.org/10.1051/apido.

[11] F. B. Daba and A. O. Wolde, "The significance of honey production for livelihood in Ethiopia," Journal of Biology, Agriculture and Healthcare, vol. 6, no. 4, pp. 46-53, 2016.

[12] G. Yirga and M. Teferi, "Participatory technology and constraints assessment to improve the livelihood of beekeepers in Tigray region, Northern Ethiopia," Mekelle University, Biology Department, College of Natural and Computational Sciences, vol. 2, no. 1, P.O. Box 3072, Mekelle, Ethiopia, 2010.

[13] Ministry of Agriculture, Non-Timber Forest Products Development Training Manuals Series. (NTFPs Integrated with Sustainable Forest Management And Livelihoods, Species, Forest Coffee, Beekeeping, Gum And Resins) (November). The Scaling-Up Participatory Forest Management Project, Natural Resources Management Directorate, 2013, Ministry of Agriculture, Addis Ababa, Ethiopia, 2013.

[14] Food and Agricultural Organization, FAOSTAT Data. Statistical Database. Livestock Primary, Food and Agriculture Organization, Rome, Italy, 2016, http://www.fao.org/faostat/ en/\#data/QL. 
[15] Central Statistical Agency, "Agricultural sample survey 2014/ 15 [2007 E. C] volume II: report on Livestock and Livestock characteristics (private peasant holdings)," in Statistical Buletin 578:Vol. II, Federal Democratic Republic of Ethiopia Central Statistical Agency (CSA), Addis Ababa, Ethiopia, 2015.

[16] I. Hartmann, "“No tree, No bee, No honey, No money": the management of resources and marginalisation in beekeeping societies of South West Ethiopia," Briding Scales and Epistemologies, Alexandria, pp. 1-12, 2004.

[17] J. Abebe, Honeybee Floral Phenology, Pollen Potential, Honey Quality and Management of Beekeeping in Three Agro-Ecologies of Sekota Woreda, Wag-Himra Zone, Amhara Region, Ethiopia, Mekelle University, Faculty of Dry land Agriculture and Natural Resources, Mekelle, Ethiopia, 2008.

[18] K. Ejigu, "Honeybee Production system, opportunities and challenges in enebse Sar Midir woreda (Amhara Region) and Amaro special wereda (SNNPR)," M.Sc. thesis, Alemaya University, Ethiopia, 2005.

[19] H. Kebede and G. Tadesse, "Survey on honey production system, challenges and Opportunities in selected areas of Hadya Zone, Ethiopia," Journal of Agricultural Biotechnology and Sustainable Development, vol. 6, no. 6, pp. 60-66, 2014.

[20] K. Ejigu, T. Gebey, and P. Tr, Constraints and Prospects for Apiculture Research and Development in Amhara Region, Ethiopia, Livestock Research for Rural Development, Colombia, 2009, http://www.lrrd.org/lrrd21/10/ejig21172. html.

[21] T. A. Abejew and Z. M. Zeleke, "Study on the beekeeping situation, the level of beekeepers knowledge concerning local honeybee subspecies, their productive characteristics, and behavior in eastern Amhara region, Ethiopia," Advances in Agriculture, vol. 2017, Article ID 6354250, 6 pages, 2017.

[22] T. Alemu, Potential Threats to Honeybee Health with Emphasis on Varroa Mite in South Wollo and Waghimra Zones of Amhara Region, Ethiopia, Bahir Dar University, College of Agriculture and Environmental Science, Bahir Dar, Ethiopia, 2015.

[23] A. Kebede, K. Ejigu, T. Aynalem, and J. Abebe, "Beekeeping in the Amhara region," in Ethiopian Institute of Agricultural Research (EIAR), A. Kirub, Ed., , http://www.eiar.gov.et, 2008.

[24] G. Godifey, "Epidemiology of honey bee disease and pests in selected zones of Tigray region, Northern Ethiopia," 2015, https://cgspace.cgiar.org/bitstream/handle/10568/77370/ thesis_Guesh_2015.pdf?sequence=1.

[25] K. Haftu, D. Daniel, B. Gebru et al., "Analysis of honeybee production opportunities and challenges in central zone of Tigray, northern Ethiopia," International Journal of Scientific and Research Publication, vol. 5, no. 4, 2015.

[26] D. Shibru, G. Asebe, and E. Megersa, "Identifying opportunities and constraints of beekeeping: the case of gambella Zuria and godere weredas, gambella regional state, Ethiopia," Entomology, Ornithology \& Herpetology: Current Research, vol. 5, no. 3, 2016.

[27] A. Bihonegn, Assessment of Beeswax Production, Quality and Market Chains in Selected Districts of South Wollo Zone, Amhara Region, Ethiopia (Issue March), Bahir Dar University, College of Agriculture and Environmental Science, Bahir Dar, Ethiopia, 2017, https://cgspace.cgiar.org/bitstream/handle/ 10568/90419/Bihonegn.pdf? sequence $=1$.

[28] T. Alemu, E. Seifu, and A. Bezabih, "Postharvest handling, opportunities and constraints to honey production in northern Ethiopia," Livestock Research for Rural Development, vol. 27, no. 5, , 2015, http://www.lrrd.org/lrrd27/5/tewo27091.html.
[29] A. Abeje, K. Ayen, M. Awoke, and L. Abebaw, "Adoption and intensity of modern bee hive in Wag Himra and north Wollo zones, Amhara region, Ethiopia," Agricultural and Resource Economics Journal, vol. 3, no. 1, pp. 5-26, 2017.

[30] H. Adal, Z. Asfaw, Z. Woldu, S. Demissew, and P. V. Damme, "An iconic traditional apiculture of park fringe communities of Borena Sayint National Park, north eastern Ethiopia an iconic traditional apiculture of park fringe communities of Borena Sayint National Park, north eastern Ethiopia," Journal of Ethnobiology and Ethnomedicine, vol. 11, no. 1, 2015.

[31] M. Miklyaev, G. P. Jenkins, and R. R. Barichello, "Honey production in Ethiopia: a cost-benefit analysis of modern versus traditional beekeeping technologies," Journal of Economic Literature, 2014.

[32] Y. Gebremeskel, B. Tamir, and D. Begna, "Characterization of bee-keeping systems and honey marketing in Eastern zone Tigray, Ethiopia," Livestock Research for Rural Development, vol. 26, no. 175, 2015, http://www.lrrd.org/lrrd26/10/ yeti26175.html.

[33] N. Yemane and M. Taye, "Honeybee production in the three Agro-ecological districts of Gamo Gofa zone of southern Ethiopia with emphasis on constraints and opportunities," Agriculture and Biology Journal of North America, vol. 4, no. 5, pp. 560-567, 2013.

[34] D. Begna, "Assessment of pesticides use and its economic impact on the apiculture subsector in selected districts of Amhara region, Ethiopia," Environmental \& Analytical Toxicology, vol. 5, no. 2, pp. 2-5, 2015.

[35] N. Bradbear, "Bees and their role in forest livelihoods. A guide to the services provided by bees and the sustainable harvesting, processing and marketing of their products," in Non-Wood Forest Products, Food and Agriculture Organization of the United Nations Regional Office for Africa, Accra, Ghana, 2009, http://ftp.fao.org/docrep/fao/012/i0842e/i0842e00.pdf.

[36] J. C. H. Saha, "Beekeeping for rural development, its potentiality and beekeeping against poverty-Bangladesh perspective," Standing Commission of Beekeeping for Rural Development, vol. 139, 2005.

[37] Abou-Shaara and F. Hossam, "The origin of honeybees' life: a viewpoint," Journal of Entomology and Zoology Studies, vol. 3, no. 1, pp. 239-241, 2015, http://www.entomoljournal.com/ vol3Issue1/pdf/3-1-65.1.pdf.

[38] P. Gallmann and H. Thomas, "Beekeeping and honey production in South Western Ethiopia," 2012, http://www.learningforlife.ch/ media/DIR_76001/76253729aa011222ffff8015a426365.pdf.

[39] T. Gebretsadik, "Survey on honeybee pests and predators in Sidama and Gedeo zones of Southern Ethiopia with emphasis on control practices," Agriculture and Biology Journal of North America, vol. 7, no. 4, pp. 173-181, 2016.

[40] G. Yirga, "Assessment of beekeeping practices in Asgede Tsimbla district, Northern Ethiopia: absconding, bee forage and bee pests," African Journal of Agricultural Research, vol. 7, no. 1, pp. 1-5, 2012.

[41] D. Tulu, M. Aleme, G. Mengistu, A. Bogale, A. Bezabeh, and E. Mendesil, "Improved beekeeping technology in South Western Ethiopia: focus on beekeepers' perception, adoption rate, and adoption determinants," Cogent Food \& Agriculture, vol. 6, no. 1, Article ID 1814070, 2020. 